\title{
Pine Wood Modification via an Antifungal Oil - Heat Treatment and its Effect on Annual Wood Rings
}

\author{
Gonca Düzkale Sözbir, ${ }^{\mathrm{a}, *}$ İbrahim Bektaş, ${ }^{\mathrm{b}}$ Ayşenur Kiliç Ak, ${ }^{\mathrm{b}}$ and Saniye Erkan ${ }^{\mathrm{b}}$
}

Thyme oil, which is an anti-fungicide, was used to increase the physical and mechanical properties of wood as well as improve its strength, especially in outdoor conditions. For this purpose, Stone pine (Pinus pinea L.) wood samples classified according to the annual number of rings were exposed to either the impregnation process or the combined process, which was comprised of impregnation followed by heat treatment. As a result of the study, it was determined that the wood had different physical and mechanical properties based upon the number of annual rings. In addition, it was specified that the thyme oil used in the impregnation process improved the physical properties of the wood and also reduced the water absorption during the combined process. As a general conclusion, the impregnation process and the combined process increased the mechanical properties of the wood in parallel with an increase in the number of annual rings. The process of impregnation of wood materials with thyme oil is promising due to its anti-fungal and antibacterial properties, its ability to be used in small amounts in on-site impregnation, and it being an environmentally friendly product for the wood protection industry.

Keywords: Pinus pinea; Thyme oil; Heat treatment; Mechanical properties

Contact information: a: Vocational School of Technical Sciences, Kahramanmaras Sutcu Imam University, Kahramanmaras 46060 Turkey; b: Kahramanmaras Sutcu Imam University, Department of Forest Industry Engineering, Faculty of Forestry, Kahramanmaraş 46100 Turkey;

*Corresponding author: goncaduzkale@gmail.com

\section{INTRODUCTION}

The field of wood material preservation is moving towards a new approach by avoiding toxic chemicals, developing new technologies, and avoiding producing negative effects on the environment. At the beginning of this approach, heat treatment of wood at high temperatures is an effective method of improving the properties of wood such as dimensional stability and durability (Esteves and Pereira 2009; Navi and Sandberg 2012). In addition, not using any chemicals in the heat treatment method makes it environmentally friendly (Garcia et al. 2012). In addition, interest in the impregnation and process development of wood materials with natural plant extracts or plant oils with anti-fungal properties has increased (Thevenon 2001; Tomak and Y1ldız 2012).

In recent years, many studies have been performed to increase the useful life of wood without using any chemicals (Metsä-Kortelainen et al. 2006; Dubey et al. 2011; Korkut 2012; Gaff and Gasparik 2013; Sozbir and Bektas 2017). In terms of impregnation processes with oils, studies have been carried out to increase the protective properties of wood via the addition of fungicides and thermicides to the oils (Palanti and Susco 2004; Lyon et al. 2007; Lyon et al. 2009). Thyme oil has been found to be effective against some white rot fungi and brown rot fungi (Voda et al. 2003; Reinprecht et al. 2019). In general, 
it has been reported that a treatment of $10 \%$ of thyme oil provides resistance to some fungal deterioration (Yang and Clausen 2008).

In this study, the effects of impregnation and heat treatment processes on the physical and mechanical properties of pine wood samples, which were subjected to heat treatment after being impregnated via dipping the wood in thyme oil (an antifungal agent), were investigated. With this study, it is important that the combined process increases some of the physical and mechanical properties of the wood material and also increases the biological resistance due to the anti-fungicide property of the oil content. Easy applicability of the process before heat treatment and the ability to use thyme oil alone are important in terms of on-site impregnation processes.

\section{EXPERIMENTAL}

\section{Materials}

There are approximately 162,000 hectares of stone pine in the areal distribution of tree species in Turkey forests and it is important to expand the usage areas of wood (TOD, 2019). Stone pine (Pinus pinea L.) trees were obtained from the town of KahramanmarasOnsen located in East Mediterranean region of Turkey. Then, the test trees were sized at an engineering workshop based on the dimensions of the test specimens required by the relevant standards mentioned below.

After the sizing process, the samples were coded and grouped. The grouping process was made with consideration to the number of annual rings. Three different groups were formed: an annual rings number less of than 10, between 10 and 25, and greater than 25.

In the study, thyme oil produced by $100 \%$ water vapor distillation was used and supplied from Mecitefendi company in Turkey.

\section{Methods}

The samples grouped based on the number of annual rings were homogeneously separated for the control, impregnation, and heat treatment processes. First, the specimens were immersed in thyme oil for $5 \mathrm{~min}$ and left under open air conditions for 3 weeks to condition. After the conditioning process, the impregnated samples were subjected to heat treatment in a laboratory drying oven at a temperature of $150{ }^{\circ} \mathrm{C}$ for $1 \mathrm{~h}$. Because, at this temperature and duration, it has been determined as the optimum process where the oil leakage problem is the least and the temperature is the highest. The test specimens sample codes and applied processes are shown in the Table 1.

Test specimens were prepared on the basis of TS standard 2470 (1976). The densities were determined with samples with dimensions of $20 \mathrm{~mm} \times 20 \mathrm{~mm} \times 30 \mathrm{~mm}$. Additionally, the static bending strength and modulus of elasticity were determined with sample dimensions of $20 \mathrm{~mm} \times 20 \mathrm{~mm} \times 300 \mathrm{~mm}$ based on TS standard 2474 (1976) and TS standard 2478 (1976), respectively. The compression strength parallel to the grain (sample dimensions of $20 \mathrm{~mm} \times 20 \mathrm{~mm} \times 30 \mathrm{~mm}$ ) and Janka hardness (sample dimensions of $50 \mathrm{~mm} \times 50 \mathrm{~mm} \times 50 \mathrm{~mm}$ ) were determined according to TS standard 2595 (1977) and TS standard 3459 (1980), respectively. For the physical properties, the volumetric shrinkage and swelling were calculated according to TS standard 4083 (1983), TS standard 4084 (1983), TS standard 4085 (1983), and TS standard 4086 (1983) with sample dimensions of $20 \mathrm{~mm} \times 20 \mathrm{~mm} \times 30 \mathrm{~mm}$. 
Table 1. Modification Process Parameters and Codes

\begin{tabular}{|c|c|c|c|}
\hline Sample Code & Annual Ring Number (N) & Impregnation Time (min) & Heat Treatment $\left({ }^{\circ} \mathrm{C}\right)$ \\
\hline A-CS & $\mathrm{N}<10$ & - & - \\
\hline A-IP & $\mathrm{N}<10$ & 5 & - \\
\hline A-HT & $\mathrm{N}<10$ & 5 & 150 \\
\hline B-CS & $10<\mathrm{N}<25$ & - & - \\
\hline B-IP & $10<\mathrm{N}<25$ & 5 & 150 \\
\hline B-HT & $10<\mathrm{N}<25$ & - & - \\
\hline C-CS & $25>\mathrm{N}$ & 5 & - \\
\hline C-IP & $25>\mathrm{N}$ & 5 & 150 \\
\hline C-HT & $25>\mathrm{N}$ & 5 & \\
\hline $\begin{array}{l}\text { Note: CS: control sample; IP: impregnation process, HT: heat treatment; A: less than } 10 \text { annual } \\
\text { rings; } \text { B: between } 10 \text { and 25 annual rings; and C: greater than 25 annual rings }\end{array}$ \\
\hline
\end{tabular}

The results were analyzed using one-way ANOVA with the SPSS statistical software program and Duncan's mean separation test to populate the homogeneity groups that showed significant differences at the $95 \%$ confidence level.

\section{Characterization of the Wood}

The cell morphologies of the samples were characterized via scanning electron microscopy (SEM) (ZEIZZ-EVO LS10) at an accelerating voltage of $10 \mathrm{kV}$. The wood samples were cut into thin slices with a Leica RM2255 microtome, then coated with gold before scanning. The structures of samples were characterized using a Fourier transform infrared spectrometer (Perkin Elmer Spectrum 400, Waltham, MA, USA). Wood samples were ground into powder, mixed with potassium bromide, and made into a tablet before testing.

\section{RESULT AND DISCUSSION}

The changes in the physical properties of the wood samples with different annual ring numbers, after modification, are shown in the Table 2. It was found that as the annual number of rings in the wood sample increased its density decreased. In this study, as the annual number of rings decreased, it exhibited young wood features. Larson et al. (2001) found that the amount of extractive substances in young wood is greater than in mature wood. The resin contained in wood is known to increase the density of the wood (Cown 2001). With regards to this information, this study explains that the density of Pinus pinea wood decreases as the number of annual rings increases. Moreover, Bektas et al. (2003) determined that Calabrian pine wood, which has resin amounts relative to its number of annual of rings of wood, decreases in density as the annual ring number increases.

From the analysis shown in Table 2, it can be understood that the density value of wood samples impregnated via the dipping method increased. Due to the fact that oil absorption increases the weight of the wood, it also increases the density (Lee et al. 2018). However, the heat treatment applied afterwards has been found to reduce the density. Sözbir and Bektaş (2017) stated that a heat treatment modification reduced the density of wood. In addition, it was found that the weight per unit volume of wood decreases as the number of annual rings increases. As the wood matures, i.e., as the number of annual rings increases, the amount of cellulose increases; accordingly, the hydrophilic cellulose 
increases the volume of the material by taking more water (Şahin 2008; Arslan and Aydemir 2009). This situation causes a decrease in the weight per unit volume.

Table 2. Comparison of the Physical Properties of Pinus pinea Wood With Relation to the Number of Annual Rings

\begin{tabular}{|c|c|c|c|c|c|}
\hline $\begin{array}{c}\text { Sample } \\
\text { Code }\end{array}$ & $\begin{array}{c}\text { Oven Dry } \\
\text { Density } \\
\left(\mathrm{g} / \mathrm{cm}^{3}\right)\end{array}$ & $\begin{array}{c}\text { Weight per unit } \\
\text { Volume }\left(\mathrm{g} / \mathrm{cm}^{3}\right)\end{array}$ & $\begin{array}{c}\text { Volumetric } \\
\text { Shrinkage }(\%)\end{array}$ & $\begin{array}{c}\text { Volumetric } \\
\text { Swelling (\%) }\end{array}$ & $\begin{array}{c}\text { Fiber Saturation } \\
\text { Point (\%) }\end{array}$ \\
\hline A-CS & $0.58 \pm 0.07 \mathrm{a}^{(*)}$ & $0.52 \pm 0.05 \mathrm{a}$ & $10.89 \pm 1.22 \mathrm{bc}$ & $11.41 \pm 1.37 \mathrm{bc}$ & $20.48 \pm 1.95 \mathrm{a}$ \\
\hline A-IP & $0.59 \pm 0.05 \mathrm{a}$ & $0.54 \pm 0.04 \mathrm{a}$ & $8.31 \pm 1.35 \mathrm{a}$ & $8.62 \pm 1.45 \mathrm{a}$ & $15.40 \pm 2.45 \mathrm{a}$ \\
\hline A-HT & $0.57 \pm 0.04 \mathrm{a}$ & $0.53 \pm 0.04 \mathrm{a}$ & $10.79 \pm 0.77 \mathrm{bc}$ & $11.38 \pm 0.86 \mathrm{bc}$ & $19.46 \pm 2.35 \mathrm{a}$ \\
\hline B-CS & $0.50 \pm 0.02 \mathrm{~b}$ & $0.45 \pm 0.02 \mathrm{~b}$ & $11.35 \pm 1.81 \mathrm{bc}$ & $12.15 \pm 1.97 \mathrm{bc}$ & $25.69 \pm 5.33 \mathrm{~b}$ \\
\hline B-IP & $0.52 \pm 0.02 \mathrm{~b}$ & $0.47 \pm 0.02 \mathrm{~b}$ & $8.74 \pm 1.87 \mathrm{a}$ & $9.17 \pm 1.85 \mathrm{a}$ & $18.61 \pm 4.48 \mathrm{a}$ \\
\hline B-HT & $0.49 \pm 0.02 \mathrm{~b}$ & $0.45 \pm 0.02 \mathrm{~b}$ & $11.52 \pm 0.50 \mathrm{bc}$ & $11.93 \pm 0.52 \mathrm{bc}$ & $25.58 \pm 1.75 \mathrm{~b}$ \\
\hline C-CS & $0.45 \pm 0.01 \mathrm{c}$ & $0.39 \pm 0.01 \mathrm{c}$ & $12.55 \pm 1.29 \mathrm{c}$ & $13.31 \pm 1.27 \mathrm{c}$ & $31.91 \pm 3.31 \mathrm{c}$ \\
\hline C-IP & $0.46 \pm 0.02 \mathrm{c}$ & $0.40 \pm 0.02 \mathrm{c}$ & $10.28 \pm 1.14 \mathrm{ab}$ & $10.76 \pm 0.12 \mathrm{ab}$ & $25.75 \pm 1.22 \mathrm{~b}$ \\
\hline C-HT & $0.44 \pm 0.02 \mathrm{c}$ & $0.40 \pm 0.01 \mathrm{c}$ & $11.95 \pm 3.85 \mathrm{bc}$ & $12.78 \pm 4.30 \mathrm{bc}$ & $30.26 \pm 9.66 \mathrm{bc}$ \\
\hline Sign. $(\boldsymbol{p})$ & 0.001 & 0.001 & 0.001 & 0.001 & 0.001 \\
\hline
\end{tabular}

Note: $\left(^{*}\right)$ means with the same letter are not significantly different in Duncan's mean separation test

Compared to the control samples, the lowest volumetric shrinkage value was obtained from the impregnated groups. Alongside the impregnated groups, the heat treatment application also decreased the volumetric shrinkage amount. When evaluating the control samples in terms of the annual ring number, a similar tendency has been observed, i.e., the lowest volumetric shrinkage was observed in the impregnated samples and then in the heat-treated samples.

As the number of annual rings in the wood samples increased, the fiber saturation point (FSP) increased, but it was found that impregnation decreased the FSP in all annual ring number groups. Impregnation with oil causes oil accumulation in the cell wall and the formation of a protective layer on the wood, which provides dimensional stability (Jalaludin et al. 2010). In different studies, the treatment of wood with oil has been evaluated and concluded that oil prevent between the wood and water relationship (Jämsä and Viitaniemi 2001; He et al. 2019).

Table 3 shows the changes in weight gain, mass loss, and water absorption according to the modification processes applied. After impregnation, the highest weight gain among the air-dried samples was obtained in group $\mathrm{C}$ and later in group $\mathrm{B}$. The highest weight loss out in groups A-HT, B-HT, and C-HT, which were subjected to heat treatment after the impregnation process, was determined to be group $\mathrm{C}(3.11 \%)$. It was determined that as the density of the wood decreases, the amount of oil it absorbs increases.

The resin amount of Pinus pinea wood is quite high (De Angelis et al. 2018). The amount of resin in young wood is higher than the amount of resin in mature wood (Arslan and Aydemir 2009). During the oil impregnation process, it is thought that the group with fewer annual rings absorbs less oil as a result of the excess resin in the cells. 
Table 3. Changes in the Weight Gain, Mass Loss, and Water Absorption Values According to Number of Annual Rings

\begin{tabular}{|c|c|c|c|c|c|c|}
\hline \multirow{2}{*}{$\begin{array}{l}\text { Sample } \\
\text { Code }\end{array}$} & \multirow{2}{*}{$\begin{array}{c}\text { Air Weight } \\
\text { Gain (\%) }\end{array}$} & \multirow{2}{*}{$\begin{array}{l}\text { Oven Dry } \\
\text { Weight } \\
\text { Gain (\%) }\end{array}$} & \multirow{2}{*}{$\begin{array}{c}\text { Mass } \\
\text { Loss (\%) }\end{array}$} & \multicolumn{3}{|c|}{ Water Absorption (\%) } \\
\hline & & & & $1 \mathrm{~h}$ & $6 \mathrm{~h}$ & $360 \mathrm{~h}$ \\
\hline A-CS & - & - & - & $5.97(2.01)$ & $11.93(4.94)$ & $53.02(11.89)$ \\
\hline A-IP & $10.7(1.7)^{(*)}$ & $1.85(0.5)$ & - & $5.74(1.46)$ & $11.31(3.43)$ & $52.90(6.799)$ \\
\hline A-HT & $9.33(1.53)$ & $1.84(0.53)$ & $1.82(0.71)$ & $4.45(1.14)$ & $10.70(2.56)$ & $51.70(9.51)$ \\
\hline B-CS & - & - & - & $12.48(5.60)$ & $20.62(7.34)$ & $73.56(6.57)$ \\
\hline B-IP & $14.32(2.53)$ & $3.96(1.3)$ & - & $11.45(4.60)$ & $19.21(5.87)$ & $72.92(4.36)$ \\
\hline B-HT & $12.84(2.4)$ & $3.52(0.91)$ & $2.77(0.63)$ & $9.05(4.48)$ & $17.19(6.02)$ & $70.85(5.82)$ \\
\hline C-CS & - & - & - & $34.87(4.55)$ & $47.94(5.99)$ & $97.66(5.48)$ \\
\hline C-IP & $15.33(1.59)$ & $4.95(0.35)$ & - & $25.63(6.47)$ & $40.84(6.56)$ & $97.51(8.20)$ \\
\hline C-HT & $16.82(2.61)$ & $4.23(0.63)$ & $3.11(0.47)$ & $28.01(3.56)$ & $37.60(4.51)$ & $95.00(5.82)$ \\
\hline
\end{tabular}

The extractive substances show hydrophobic properties, and since the A-CS, A-IP, and A-HT groups contain more extractive substances, there is less free and bound water (Singh et al. 2011). This situation caused less mass loss during the heat treatment, as it made heat transfer more difficult. In addition, during the heat treatment, as there is a high rate of hemicellulose in the mature wood, the total mass loss is greater (Rowel 2005). Hemicellulose is the first wood component to be affected by heat treatment and causes an increase in mass loss (Esteves and Pereira 2009). Likewise, the water intake value decreases as the annual number of rings decreases. The least amount of water absorption was realized in impregnated wood treated with heat in A-HT group, which had the least number of annual rings. In this study, the most effective method to reduce water absorption is the impregnated heat treatment method (HT process).

The effects of the modification process on the mechanical properties according to the number of rings per year are shown in Table 4.

Table 4. Effect of the Modification Process on the Mechanical Properties According to Number of Annual Rings

\begin{tabular}{|c|c|c|c|c|}
\hline $\begin{array}{c}\text { Sample } \\
\text { Code }\end{array}$ & $\begin{array}{c}\text { Compression } \\
\text { Strength } \\
\left(\mathrm{N} / \mathrm{mm}^{2}\right)\end{array}$ & $\begin{array}{c}\text { Bending } \\
\text { Strength } \\
\left(\mathrm{N} / \mathrm{mm}^{2}\right)\end{array}$ & $\begin{array}{c}\text { Modulus of } \\
\text { Elasticity } \\
\left(\mathrm{N} / \mathrm{mm}^{2}\right)\end{array}$ & $\begin{array}{c}\text { Janka } \\
\text { Hardness } \\
\left(\mathrm{N} / \mathrm{mm}^{2}\right)\end{array}$ \\
\hline A-CS & $46.87 \pm 3.72 \mathrm{a}$ & $69.92 \pm 13.22 \mathrm{a}$ & $5708 \pm 1427 \mathrm{ab}$ & $50.16 \pm 10.22 \mathrm{a}$ \\
\hline A-IP & $48.76 \pm 4.63 \mathrm{~cd}$ & $73.10 \pm 12.26 \mathrm{ab}$ & $6081 \pm 876 \mathrm{ab}$ & $50.80 \pm 8.69 \mathrm{a}$ \\
\hline A-HT & $52.44 \pm 4.05 \mathrm{~d}$ & $77.68 \pm 8.74 \mathrm{ab}$ & $5509 \pm 1477 \mathrm{a}$ & $51.24 \pm 6.31 \mathrm{a}$ \\
\hline B-CS & $42.13 \pm 2.59 \mathrm{ab}$ & $83.96 \pm 9.76 \mathrm{ab}$ & $6334 \pm 605 \mathrm{ab}$ & $44.41 \pm 11.08 \mathrm{a}$ \\
\hline B-IP & $45.73 \pm 2.85 \mathrm{bc}$ & $84.64 \pm 9.25 \mathrm{ab}$ & $6434 \pm 589 \mathrm{ab}$ & $46.47 \pm 10.79 \mathrm{a}$ \\
\hline B-HT & $46.80 \pm 2.29 \mathrm{c}$ & $89.92 \pm 19.13 \mathrm{~b}$ & $6195 \pm 959 \mathrm{ab}$ & $47.77 \pm 11.88 \mathrm{a}$ \\
\hline C-CS & $39.76 \pm 4.21 \mathrm{a}$ & $83.63 \pm 4.74 \mathrm{ab}$ & $6788 \pm 750 \mathrm{ab}$ & $43.43 \pm 9.62 \mathrm{a}$ \\
\hline C-IP & $41.76 \pm 1.24 \mathrm{ab}$ & $84.33 \pm 16.85 \mathrm{ab}$ & $7034 \pm 573 \mathrm{~b}$ & $45.42 \pm 11.42 \mathrm{a}$ \\
\hline C-HT & $45.70 \pm 5.03 \mathrm{bc}$ & $88.70 \pm 6.12 \mathrm{ab}$ & $6715 \pm 800 \mathrm{ab}$ & $46.10 \pm 13.25 \mathrm{a}$ \\
\hline Sign. $(\boldsymbol{p})$ & $<0.050$ & $<0.050$ & $<0.050$ & $>0.050$ \\
\hline
\end{tabular}


The highest compression strength value was obtained in group A, which had the lowest number of annual rings. Among the group A samples, the highest value was observed in the AHT group, which was subjected to combined modification. Tomak et al. (2011) and Bak and Nemeth (2012a) reported that an oil treatment increased the compression strength and the reason for this increase was that the oil filled the wood cell lumen and thickened the cell wall. Heat treatment performed after impregnation caused the greatest increase in compression strength of the tested methods. The reason for this is that the increase in the amount of lignins during the heat treatment caused an increase in strength (Yıldiz et al. 2006; Bektaş et al. 2017).

The combined process (impregnation + heat treatment) yielded the highest bending strength values when the samples were evaluated according to their modification process. The bending strength values of the A-CS, A-IP, and A-HT groups, which have fewer rings per year, were significantly lower. Bao et al. (2001) compared the mechanical properties of multiple mature wood and young wood species, and as a result, determined that the strength values of young wood were lower than the strength values of mature wood.

As the number of rings increased annually, the modulus of elasticity increased. Impregnation with oil increased the modulus of elasticity, but heat treatment decreased it. Other studies support the result that the modulus of elasticity increases when the samples are subjected to oil impregnation (Kocaefe et al. 2008; Bak and Nemetz 2012b). It is stated in many studies that the heat treatment of wood decreases the modulus of elasticity (Bekhta and Niemz 2003; Korkut et al. 2008; Düzkale Sözbir et al. 2017).

A higher hardness value was obtained in group A, which had a lower number of rings per year. Both oil impregnation and the combined process (impregnation + heat treatment) increased the hardness values. Since the number of rings per year was less and the amount of extractive material was greater in group A, a higher hardness value was found compared to other the groups. Brémaud et al. (2011) stated that the extractive substance in the wood moderately affects the hardness value. The reason for the highest increase in hardness due to the combined process is thought to be the increase in the amount of lignins.

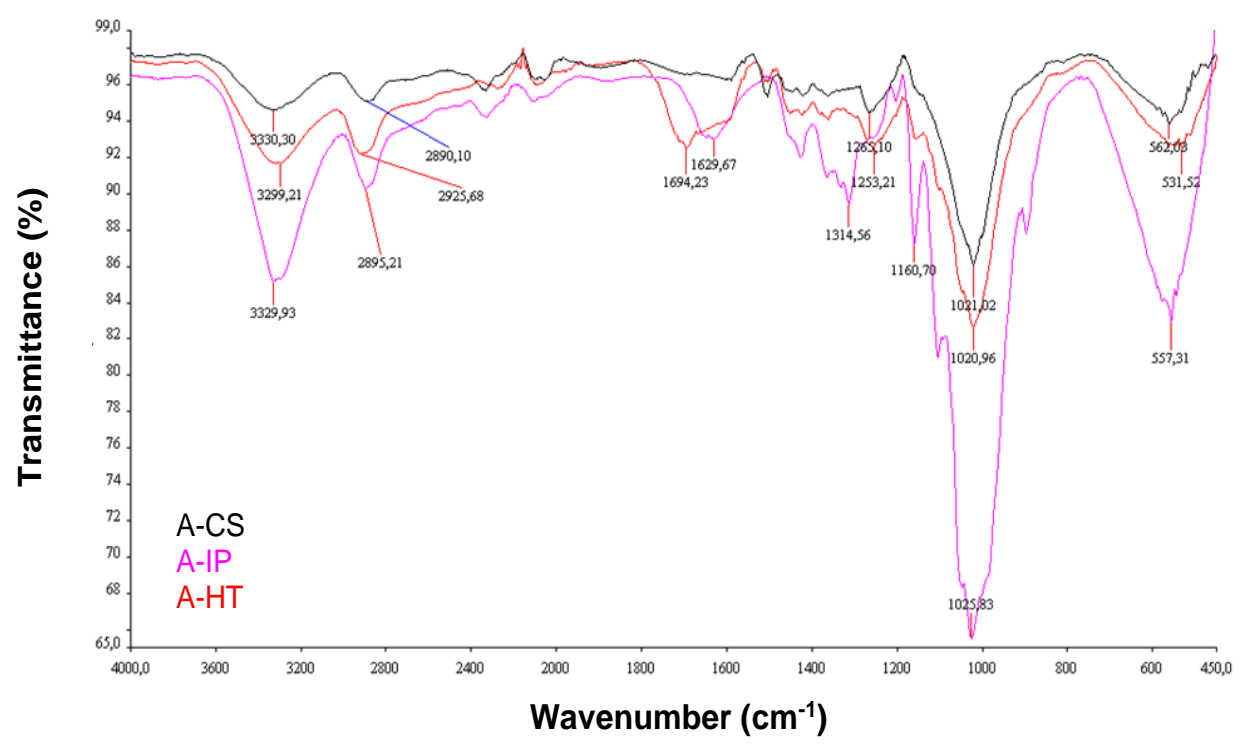

Fig. 1. FTIR spectra of the A-CS, A-IP, and A-HT samples 
Figure 1 shows the FTIR spectroscopy results of the A-CS, A-IP, and A-HT groups. The wavelengths ranging from 3330 to $3400 \mathrm{~cm}^{-1}$ show the $\mathrm{OH}$ stretching of alcohols, phenols, and acids (Gönültaş and Candan 2018). The -OH stretching of A-CS at a wavelength of $3330 \mathrm{~cm}^{-1}$ length decreased to a wavelength of $3299 \mathrm{~cm}^{-1}$ in the A-HT group. This is an indication that the heat treatment reduces the absorbance associated with -OH stretching. Additionally, the impregnation process had a minor effect on $\mathrm{OH}$ stretching. The wavelengths ranging from 2850 to $2970 \mathrm{~cm}^{-1}$ correspond to the $\mathrm{C}-\mathrm{H}$ stretching (Esteves et al. 2013).

The C-H bond was found at a wavelength of $2890 \mathrm{~cm}^{-1}$ in the A-CS samples, a wavelength of $2895 \mathrm{~cm}^{-1}$ in the A-IP samples, and a wavelength of $2926 \mathrm{~cm}^{-1}$ in the A-HT samples. For the $\mathrm{C}-\mathrm{H}$ stretching, the apparent change in frequency is due to changes in the structural and relative wood components, i.e., the degree of crystallinity of cellulose and the change in lignin methoxyl groups (Coates 2000; Moharram and Mahmoud 2008; Spiridon et al. 2011).

There was an absorbance band for $\mathrm{C}=\mathrm{C}$ stretching at a wavelength of $1600 \mathrm{~cm}^{-1}$ in thyme oil. While this band was observed at a wavelength of $1629 \mathrm{~cm}^{-1}$ in A-IP, it was seen at higher wavelengths $\left(1694 \mathrm{~cm}^{-1}\right)$ in group A-HT, which underwent both the thyme oil and heat treatments. González-Peña et al. (2009) attributed the heat treatment to the increase of conjugated carbonyl groups in the lignins.
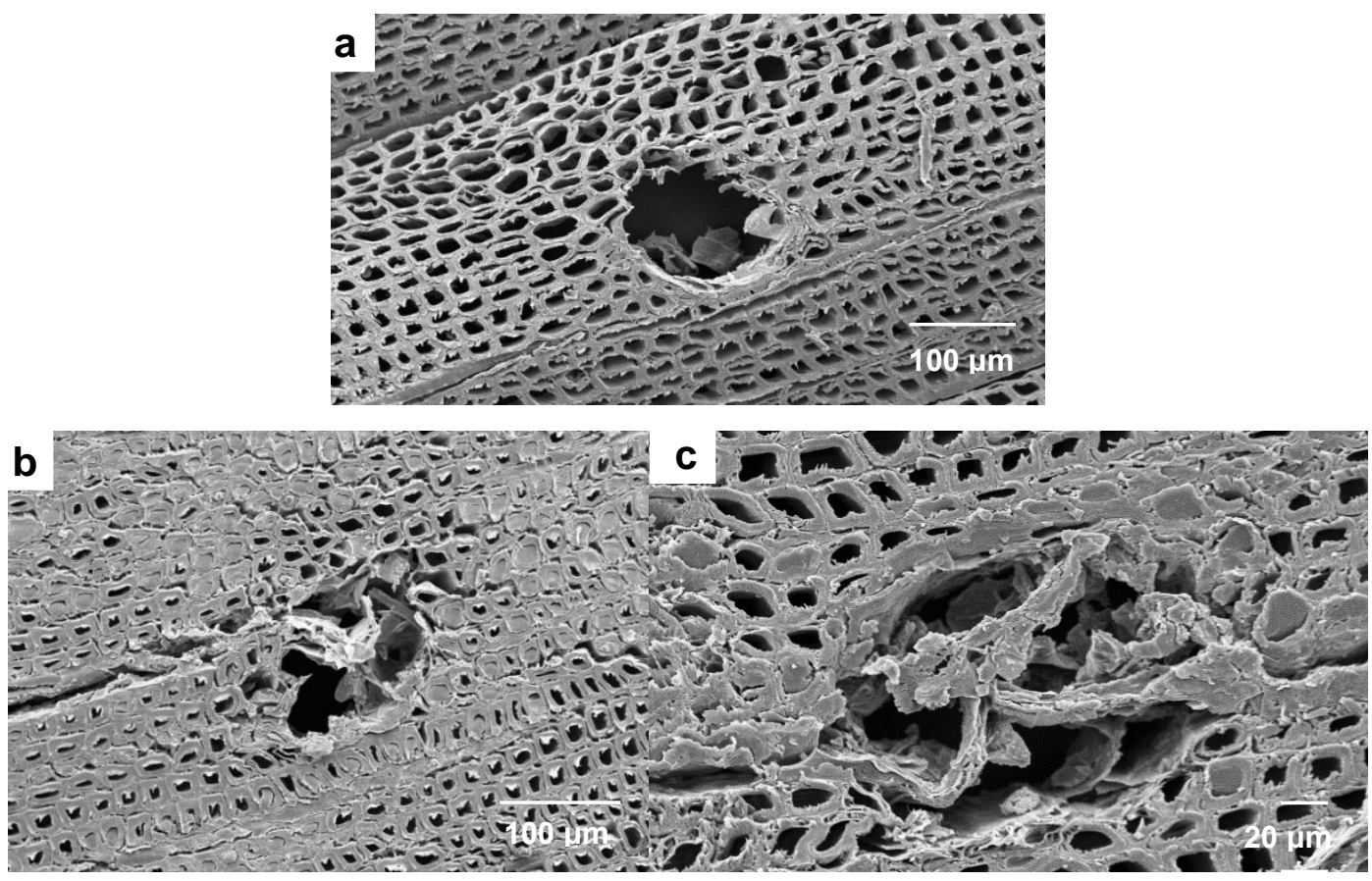

Fig. 2. SEM images of the control group (a) and the thyme oil treatment group (b) images taken at approximately 500x and the thyme oil treatment + heat treatment group images taken at $1.00 \mathrm{Kx}$

Lignin S units and $\mathrm{G}$ units are seen at wavelengths ranging from $1240 \mathrm{~cm}^{-1}$ to 1320 $\mathrm{cm}^{-1}$ (Esteves et al. 2013). The increase in the lignin unit wavelengths $\left(1314 \mathrm{~cm}^{-1}\right)$ in the A-HT group is related to the increase in lignin density. The same phenomenon was reported by Windeisen et al. (2007). The reason for the lignin unit wavelength increase in the A-IP group $\left(1265 \mathrm{~cm}^{-1}\right)$ is that the thymol in thyme oil (seen at a wavelength of $1289 \mathrm{~cm}^{-1}$ ) enters the wood structure and increases the density (Valderrama and De 2017). Valderrama and 
De (2017) found that the presence of carvacrol in the thyme yielded a wavelength of 1173 $\mathrm{cm}^{-1}$. The presence of carvacrol attached to the structure in the samples of the A-HT group was seen at a wavelength of $1161 \mathrm{~cm}^{-1}$. The C-O-C deformation peak was higher in the AHT group. This situation is thought to be caused by the heat treatment.

The SEM micrographs of the group A samples treated in different ways are shown in Fig. 2. The A-CS group image (Fig. 2a) shows the resin channels and the cell walls of the wood samples. Looking at the SEM image of the A-IP group samples (Fig. 2b), it can be seen that thyme oil fills the cell lumens. This can explain the increased weight gain in the samples. In the A-HT group samples, the resin and oil leakage as well as the deterioration of the cell structure are clearly seen. In addition, the cell deformation has been found to be caused by heat treatment. This is the reason for the weight loss, decrease in density, and the low mechanical properties of the samples. In addition, this is the reason for the weight loss and the decrease in density in the samples.

\section{CONCLUSIONS}

1. The density and the weight per unit of volume decreased as the number of annual rings increased, and its relationship with extractives has been reported.

2. Since the number of annual rings is evaluated within itself, the lowest volumetric shrinkage, volumetric swelling, and FSP were determined in the group impregnated with thyme oil. The impregnation process provided water repellent properties to lignocellulosic material, and this could be beneficial in the products used in outdoor conditions.

3. In the study, weight gain of the samples under air-dry conditions was determined to be approximately $9 \%$ to $17 \%$ compared to the annual rings, and this ratio is considered sufficient to provide resistance against fungus.

4. It was concluded that the combined process (impregnation + heat treatment) is more effective in samples exposed to water for a long time.

5. It was determined that just the impregnation process with thyme oil or in combination with heat treatment increased the strength values, but the combined process decreased the modulus of elasticity in groups A-HT, B-HT, C-HT. It was clearly seen that the heat treatment reduced the elasticity of the wood.

6. According to the results of the FTIR analysis, the combined process provided the greatest reduction in hydroxyl groups. With the procedures applied, it was concluded that the thymol and carvacrol found in thyme oil were bonded.

\section{REFERENCES CITED}

Arslan, M. B., and Aydemir, D. (2009). “Juvenile wood and its properties," Journal of Bartin Faculty of Forestry 11(16), 25-32.

Bak, M., and Németh, R. (2012a). "Changes in swelling properties and moisture uptake rate of oil-heat-treated poplar (Populus $\times$ euramericana cv. Pannonia) wood," BioResources 7(7), 5128-5137. DOI: 10.15376/biores.7.4.5128-5137 
Bak, M., and Nemeth, R. (2012b). "Modification of wood by oil heat treatment," in: Proceedings of the International Scientific Conference on Sustainable Development\& Ecological Footprint, 26-27 March, Sopron, Hungary, pp. 1-5.

Bao, F. C., Jiang, Z. H., Jiang, X. M., Lu, X. X., Luo, X. Q., and Zhang, S. Y. (2001). "Differences in wood properties between juvenile wood and mature wood in 10 species grown in China," Wood Science and Technology 35(4), 363-375. DOI: $10.1007 / \mathrm{s} 002260100099$

Bekhta, P., and Niemz, P. (2003). "Effect of high temperature on the change in color, dimensional stability and mechanical properties of spruce wood," Holzforschung 57(5), 539-546. DOI: 10.1515/HF.2003.080

Bektas, I., Alma, M. H., Goker, Y., Yuksel, A., and Gundogan, R. (2003). "Influence of site on sapwood and heartwood ratios of Turkish calabrian pine," Forest Products Journal 53(4), 48-50.

Bektaş, İ., Sözbir, G. D., Bal, B. C., and Altuntaş, E. (2017). "Effects of the thermal and thermally compressed modification treatments on chemical properties of the poplar woods," Kahramanmaraş Sütçü Imam University Journal of Engineering Sciences 20(1), 31-37. DOI: 10.17780/ksujes.287672

Brémaud, I., Amusant, N., Minato, K., Gril, J., and Thibaut, B. (2011). "Effect of extractives on vibrational properties of African Padauk (Pterocarpus soyauxii Taub.)," Wood Science and Technology 45(3), 461-472. DOI: 10.1007/s00226-0100337-3

Coates, J. (2000). "Interpretation of infrared spectra, a practical approach," in: Encyclopedia of Analytical Chemistry: Applications, Theory and Instrumentation, R. A. Meyers (ed.), John Wiley \& Sons Ltd, Hoboken, NJ, pp. 10815-10837.

Cown, D. J. (2001). "Wood: Density," in: Encyclopedia of Materials: Science and Technology (Second Edition), K. H. J. Buschow, R. W. Cahn, M. C. Flemings, B. Ilschner, E. J. Kramer, S. Mahajan, and P. Veyssière (ed.), Pergamon Press, Oxford, United Kingdom, pp. 9620-9622.

De Angelis, M., Romagnoli, M., Vek, V., Poljanšek, I., Oven, P., Thaler, N., Lesar, B., Kržišnik, D., and Humar, M. (2018). "Chemical composition and resistance of Italian stone pine (Pinus pinea L.) wood against fungal decay and wetting," Industrial Crops and Products 117, 187-196. DOI: 10.1016/j.indcrop.2018.03.016

Dubey, M. K., Pang, S., and Walker, J. (2011). "Effect of oil heating age on colour and dimensional stability of heat-treated Pinus radiata," European Journal of Wood and Wood Products 69(2), 255-262. DOI: 10.1007/s00107-010-0431-0

Esteves, B. M., and Pereira, H. M. (2009). "Wood modification by heat treatment: A review," BioResources 4(1), 370-404. DOI: 10.15376/biores.4.1.370-404

Esteves, B., Marques, A. V., Domingos, I., and Pereira, H. (2013). "Chemical changes of heat-treated pine and eucalypt wood monitored by FTIR," Maderas. Ciencia y Tecnología 15(2), 245-258. DOI: 10.4067/S0718-221X2013005000020

Gaff, M., and Gašparík, M. (2013). "Shrinkage and stability of thermo-mechanically modified aspen wood," BioResources 8(1), 1136-1146. DOI:

10.15376/biores.8.1.1136-1146

Garcia, R. A., Carvalho, A. M., Latorraca, J. V. F., Matos, J. L. M., Santos, W. A., and Silva, R. F. M. (2012). "Non destructive evaluation of heat-treated Eucalyptus grandis Hill ex Maiden wood using stress wave method." Wood Science Technolgy 46, 41-52. DOI: 10.1007/s00226-010-0387-6. 
Gonultas, O., and Candan, Z. (2018). "Chemical characterization and FTIR spectroscopy of thermally compressed eucalyptus wood panels," Maderas. Ciencia y Tecnología 20(3), 431-442. DOI: 10.4067/S0718-221X2018005031301

González-Peña, M. M., Curling, S. F., and Hale, M. D. C. (2009). "On the effect of heat on the chemical composition and dimensions of thermally-modified wood," Polymer Degradation and Stability 94(12), 2184-2193. DOI:

10.1016/j.polymdegradstab.2009.09.003

He, Z., Qian, J., Qu, L., Yan, N., and Yi, S. (2019). "Effects of Tung oil treatment on wood hygroscopicity, dimensional stability and thermostability," Industrial Crops and Products 140, Article ID 111647. DOI: 10.1016/j.indcrop.2019.111647

Jalaludin, Z., Hill, C. A. S., Samsi, H. W., Husain, H., and Xie, Y. (2010). “Analysis of water vapour sorption of oleo-thermal modified wood of Acacia mangium and Endospermum malaccense by a parallel exponential kinetics model and according to the Hailwood-Horrobin model," Holzforschung 64, 763-770. DOI: 10.1515/hf.2010.100

Jämsä, S., and Viitaniemi, P. (2001). "Heat treatment of wood - Better durability without chemicals," in: Proceedings of Special Seminar, 9 February, Antibes, France.

Kocaefe, D., Poncsak, S., and Boluk, Y. (2008). "Effect of thermal treatment on the chemical composition and mechanical properties of birch and aspen," BioResources 3(2), 517-537. DOI: 10.15376/biores.3.2.517-537

Korkut, S. (2012). "Performance of three thermally treated tropical wood species commonly used in Turkey," Industrial Crops and Products 36 (1), 355-362. DOI: 10.1016/j.biortech.2007.03.038

Korkut, S., Akgül, M., and Dündar, T. (2008). "The effects of heat treatment on some technological properties of Scots pine (Pinus sylvestris L.) wood," Bioresource Technology 99(6), 1861-1868. DOI: 10.1016/j.biortech.2007.03.038

Larson, P. R., Kretschmann, D. E., Clark, A. III., and Isebrands, J. G. (2001). Formation and Properties of Juvenile Wood in Southern Pines: A Synopsis (FPL-GTR-129), U. S. Department of Agriculture, Forest Products Laboratory, Madison, WI.

Lee, S. H., Ashaari, Z., Lum, W. C., Halip, J. A., Ang, A. F., Tan, L. P., Chin K. L., and Tahir, P. M. (2018). "Thermal treatment of wood using vegetable oils: A review," Construction and Building Materials 181, 408-419. DOI: 10.1016/j.conbuildmat.2018.06.058

Lyon, F., Thévenon, M.-F., Pizzi, A., and Gril, J. (2009). "Resistance to decay fungi of ammonium borate oleate treated wood," in: Proceedings of the $40^{\text {th }}$ Annual Meeting of the International Research Group on Wood Protection, 24-28 May, Beijing, China, pp. 1-10.

Lyon, F., Thévenon, M.-F., Imamura, Y., Gril, J., and Pizzi, A. (2007). "Development of boron/linseed oil combined treatment as a low-toxic wood protection. Evaluation of boronfixation and resistance to termites according to Japanese and European standards," in: Proceedings of the IRG Regional Research Symposium, 29 October - 2 November, Taipei, Taiwan, pp. 1-12.

Metsä-Kortelainen, S., Antikainen, T., and Viitaniemi, P. (2006). "The water absorption of sapwood and heartwood of Scots pine and Norway spruce heat-treated at $170{ }^{\circ} \mathrm{C}$, $190{ }^{\circ} \mathrm{C}, 210^{\circ} \mathrm{C}$ and $230^{\circ} \mathrm{C}$," Holz als Roh- und Werkstoff 64(3), 192-197. DOI: 10.1007/s00107-005-0063-y

Moharram, M. A., and Mahmoud, O. M. (2008). "FTIR spectroscopic study of the effect of microwave heating on the transformation of cellulose I into cellulose II during 
mercerization," Journal of Applied Polymer Science 107(1), 30-36. DOI:

10.1002/app. 26748

Navi, P., and Sandberg, D. (2012). Thermo-hydro-mechanical Wood Processing, CRC Press.

Palanti, S., and Susco, D. (2004). "A new wood preservative based on heated oil treatment combined with triazole fungicides developed for above-ground conditions," International Biodeterioration \& Biodegradation 54(4), 337-342. DOI: 10.1016/j.ibiod.2004.04.003

Reinprecht, L., Pop, D. M., Vidholdová, Z., and Timar, M. C. (2019). “Antidecaypotential of five essential oils against the wood-decaying fungi Serpula lacrymans and Trametes versicolor," Acta Facultatis Xylologiae Zvolenres Publica Slovaca 61(2), 63-72. DOI: 10.17423/afx.2019.61.2.06

Rowell, R. M., 2005. Handbook of Wood Chemistry and Wood Composites, CRC Press, Boca Raton, FL.

Sahin, H. T. (2008). "Wood-water interactions as affected by chemical constituents of woods," Asian Journal of Chemistry 20(4), 3267-3276.

Singh, S. K., Ghnimi, S., and Trébouet, D. (2011). "Studies on development on methodology for extraction of phenolic compound from hydro-alcoholic wood extracts," Separation Science and Technology 46(5), 720-726. DOI: 10.1080/01496395.2010.534758

Sözbir, G. D., and Bektaş, İ. B. (2017). "The effect of heat modification and densification on physical properties of poplar wood," Drvna industrija: Znanstveni Časopis za Pitanja Drvne Tehnologije 68(4), 315-321. DOI: 10.5552/drind.2017.1719

Sözbir, G. D., Bektas, I., and Ak, A. K. (2019). "Influence of combined heat treatment and densification on mechanical properties of poplar wood," Maderas. Ciencia y Tecnología 21(4), 481-492. DOI: 10.4067/S0718-221X2019005000405

Spiridon, I., Teacă, C. A., and Bodîrlău, R. (2011). "Structural changes evidenced by FTIR spectroscopy in cellulose materials after pre-treatment with ionic liquid and enzymatic hydrolysis," BioResources 6(1), 400-413. DOI: 10.15376/biores.6.1.400413

Thevenon, M.-F. (2001). "Oils and water repellents in wood protection: Research and development in France," in: Proceedings of the Special Seminar on Oils and Water Repellents in Wood Preservation, 9 November, Reinbek, Germany, pp. 1-6.

TOD (2019). The Foresters' Association of Turkey, ISBN: 978-975-93478-4-0.

Tomak, E. D., and Yıldız, U. C., (2012). "Applicability of vegetable oils as a wood preservative," Artvin Çoruh University Journal Faculty of Forestry 13(1), 142-157.

Tomak, E. D., Viitanen, H., Yildiz, U. C., and Hughes, M. (2011). "The combined effects of boron and oil heat treatment on the properties of beech and Scots pine wood. Part 2: Water absorption, compression strength, color changes, and decay resistance," Journal of Materials Science 46(3), 608-615. DOI: 10.1007/s10853-010-4860-2

TS 2470 (1976). "Wood - Sampling methods and general requirements for physical and mechanical tests," Turkish Standards Institution, Ankara, Turkey.

TS 2474 (1976). "Wood - Determination of ultimate strength in static bending," Turkish Standards Institution, Ankara, Turkey.

TS 2478 (1976). "Wood - Determination of modulus of elasticity in static bending," Turkish Standards Institution, Ankara, Turkey.

TS 2595 (1977). "Wood - Determination of ultimate stress in compression parallel to grain," Turkish Standards Institution, Ankara, Turkey. 
TS 3459 (1980). "Wood - Determination of ultimate shearing stress parallel to grain," Turkish Standards Institution, Ankara, Turkey.

TS 4083 (1983). "Wood - Determination of radial and tangential swelling," Turkish Standards Institution, Ankara, Turkey.

TS 4084 (1983). "Wood - Determination of radial and tangential swelling," Turkish Standards Institution, Ankara, Turkey.

TS 4085 (1983). "Wood - Determination of volumetric shrinkage," Turkish Standards Institution, Ankara, Turkey.

TS 4086 (1983). "Wood - Determination of volumetric shrinkage," Turkish Standards Institution, Ankara, Turkey.

Valderrama, A. C. S., and De, G. C. R. (2017). "Traceability of active compounds of essential oils in antimicrobial food packaging using a chemometric method by ATRFTIR," American Journal of Analytical Chemistry 8(11), 726-741. DOI: 10.4236/ajac.2017.811053

Voda, K., Boh, B., Vrtačnik, M., and Pohleven, F. (2003). "Effect of the antifungal activity of oxygenated aromatic essential oil compounds on the white-rot Trametes versicolor and the brown-rot Coniophora puteana," International Biodeterioration \& Biodegradation 51(1), 51-59. DOI: 10.1016/S0964-8305(02)00075-6

Windeisen, E., Strobel, C., and Wegener, G. (2007). "Chemical changes during the production of thermo-treated beech wood," Wood Science and Technology 41(6), 523-536. DOI: 10.1007/s00226-007-0146-5

Yang, V. W., and Clausen, C. A. (2008). "Inhibitory effect of essential oils on decay fungi and mold growth on wood," in: Proceedings of the 103 ${ }^{\text {rd }}$ Annual Meeting of the American Wood Protection Association, 6-8 May, St. Louis, MO, pp. 62-70.

Yildiz, S., Gezer, E. D., and Yildiz, U. C. (2006). "Mechanical and chemical behavior of spruce wood modified by heat," Building and Environment 41(12), 1762-1766. DOI: 10.1016/j.buildenv.2005.07.017

Article submitted: March 10, 2021; Peer review completed: May 1, 2021; Revised version received and accepted: May 3, 2021; Published: May 5, 2021.

DOI: $10.15376 /$ biores.16.3.4731-4742 